\title{
Potential molecular approaches for the early diagnosis of lung cancer (Review)
}

\author{
CHUL HO OAK ${ }^{1}$, DONALD WILSON ${ }^{3}$ HU JANG LEE ${ }^{4}$, HO-JU LIM ${ }^{5}$ and EUN-KEE PARK ${ }^{2}$
}

\author{
Departments of ${ }^{1}$ Internal Medicine, and ${ }^{2}$ Medical Humanities and Social Medicine, College of Medicine, Kosin University, \\ Busan, Republic of Korea; ${ }^{3}$ Department of Occupational Toxicology, Institute of Industrial Ecological Sciences, \\ University of Occupational and Environmental Health, Kitakyushu, Japan; ${ }^{4}$ Research Institute of Life Sciences, \\ College of Veterinary Medicine, Gyeongsang National University, Chinju; ${ }^{5}$ Indoor Environment and Noise \\ Research Division, National Institute of Environmental Research, Incheon, Republic of Korea
}

Received April 9, 2012; Accepted August 13, 2012

DOI: $10.3892 / \mathrm{mmr} .2012 .1042$

\begin{abstract}
Lung cancer is the leading cause of mortality from cancer among men and women worldwide. More individuals die each year of lung cancer than of colon, breast and prostate cancer combined. Despite new diagnostic techniques, the overall 5-year survival rate remains at approximately $15 \%$ and the majority of patients still present with advanced disease. Therefore, lung cancer is the most lethal cancer at present. Diagnosing and treating cancer at its early stages, ideally during the precancerous stages, could increase the 5-year survival rate by 3-4-fold, with the possibility of cure. To date, no screening method has been shown to decrease the disease-specific mortality rate. This review describes issues related to early lung cancer screening and their rationale, the management of primary cancers detected by screening and the different approaches that have been tested for cancer screening; these include imaging techniques, bronchoscopies and molecular screening, such as analysis of epigenomics using different noninvasive or invasive sources, such as blood, sputum, bronchoscopic samples and exhaled breath.
\end{abstract}

\section{Contents}

1. Introduction

2. Biomarkers of lung cancer

3. Conclusion

Correspondence to: Dr Donald Wilson, Department of Occupational Toxicology, Institute of Industrial Ecological Sciences, University of Occupational and Environmental Health, 1-1 Iseigaoka, Yahatanishi-ku, Kitakyushu 807-8555, Japan

E-mail: wilson@med.uoeh-u.ac.jp

Dr Hu Jang Lee, Research Institute of Life Sciences, College of Veterinary Medicine, Gyeongsang National University, 900 Gajwa-dong, Chinju 660-701, Republic of Korea

E-mail: hujang@gnu.ac.kr

Key words: biomarkers, early diagnosis, epigenomics, lung cancer

\section{Introduction}

Lung cancer is the leading cause of cancer-related mortality in the world, and $85 \%$ of cases are caused by tobacco smoke (1). Other established risk factors for lung cancer are exposure to second-hand cigarette smoke, occupational exposure to agents such as asbestos, nickel, chromium or arsenic, exposure to radiation, including radon gas in homes, and exposure to air pollution (2).

The International Agency for Research on Cancer (IARC) estimated in 2008 (3) that the crude incidence and mortality of cancer was 12.7 and 7.6 million cases, respectively, of which $56 \%$ of new cancer cases and $63 \%$ of cancer deaths occur in the less developed regions of the world. The most commonly diagnosed ( $\mathrm{N}$, proportion of total) cancers worldwide are lung (1.61 million, 12.7\%), breast (1.38 million, 10.9\%) and colorectal cancers (1.23 million, 9.7\%). Furthermore, the most common causes ( $\mathrm{N}$, proportion of total) of cancer mortality are lung (1.38 million, $18.2 \%)$, stomach $(738,000,9.7 \%)$ and liver cancer $(696,000,9.2 \%)$.

In Korea, according to the 2008 annual report of cancer statistics (4), the number of new cancer cases was 178,816 , a $7.8 \%$ increase compared to that of 2007. The crude incidence rate of cancer in 2008 was 361.9 per 100,000, a $26 \%$ increase compared to that of 2001. Stomach cancer was the most common form, while lung cancer was the 4th most common. Furthermore, lung cancer is the most frequent cancer in males over 65 years of age. The 5-year survival rate of lung cancer between 2004 and 2008 was $17.5 \%$, an increase of $4.8 \%$ compared to that of the period between 1996 and 2000 (4).

In the United States, $75 \%$ of patients with lung cancer present symptoms of advanced incurable disease (5). Despite advances in the treatment of lung cancer, the 5-year survival rate for all stages combined is approximately $16 \%$ (6). Patients diagnosed at earlier stages inevitably have a significantly improved 5-year survival rate: $60-75 \%$ for stage I disease (7). An efficacious screening test that could result in early detection and reduced mortality would thus represent a major advance in dealing with lung cancer mortality.

Early detection would be a significant step towards reducing lung cancer incidence and mortality. However, 
conventional diagnostic methods for lung cancer are unsuitable for widespread screening, as they are commonly expensive and occasionally miss tumors or invasive cancers (8-11). Computed tomography (CT) is widely used for early screening of lung cancer, although it often produces high false-positive rates $(12,13)$. Better diagnostic methods are urgently required to improve the detection of lung cancer. Tissue and blood have been used extensively for the early detection of lung cancer (14-16). The detection of aberrant promoter methylation or metal ions in sputum has also been used (17-19). Monoclonal antibody detection, fluorescence bronchoscopy and low-dose spiral CT increase diagnostic sensitivity and improve the ability to localize early-stage lesions (20), but the screening methods are limited by the sample availability or composition variability.

Recently, biomarker discovery and their clinical use have been accelerated by the completion of the human genome project and the progress of techniques in proteomics (21). Numerous potential DNA biomarkers have been discovered as lung cancer biomarkers (22). Progress has consequently been made in early diagnosis, therapy guidance and prognosis monitoring of cancers.

In this review, we discuss various molecular biomarkers of lung cancer, and how reported individual biomarkers could be used for the early diagnosis of lung cancer.

\section{Biomarkers of lung cancer}

Due to the vast development of knowledge over the past several decades, different methods have been suggested to classify lung cancer biomarkers. However, these classifications should be considered in context, as identification of lung cancer biomarkers is one of the major multidisciplinary areas in the biomedical field. A schematic for the classification of biomarkers is shown in Fig. 1.

Predictive, diagnostic and prognostic biomarkers of lung cancer. Prognostic biomarkers are based on the distinguishing features between benign and malignant tumors. They could be selected based on the differentiation status of tumors, which may affect clinicians' decisions related to treatment modalities. For example, the lung metagene model predicted recurrence for individual patients significantly better than clinical prognostic factors and was consistent across all early stages of lung cancer $(23,24)$. Such markers are also important from the point of view of predicting relapse of lung cancer.

Predictive biomarkers, occasionally referred to as response markers, are utilized exclusively in assessing the effect of administration of a specific drug. These biomarkers allow clinicians to select a set of chemotherapeutic agents that will work best for an individual patient. For example, gefitinib is useful in non-small cell lung cancer (NSCLC) showing only epidermal growth factor receptor (EGFR) mutation $(25,26)$. Consequently, EGFR mutation is a predictive lung cancer biomarker.

Diagnostic markers may be present in any stage during cancer development $(27,28)$. Carcinoembryonic antigen (CEA) in NSCLC is an example of a diagnostic marker present in the early stages of lung cancer. Moreover, a diagnostic cancer marker could be specific to stage, tissue, relapse, follow-up and age.

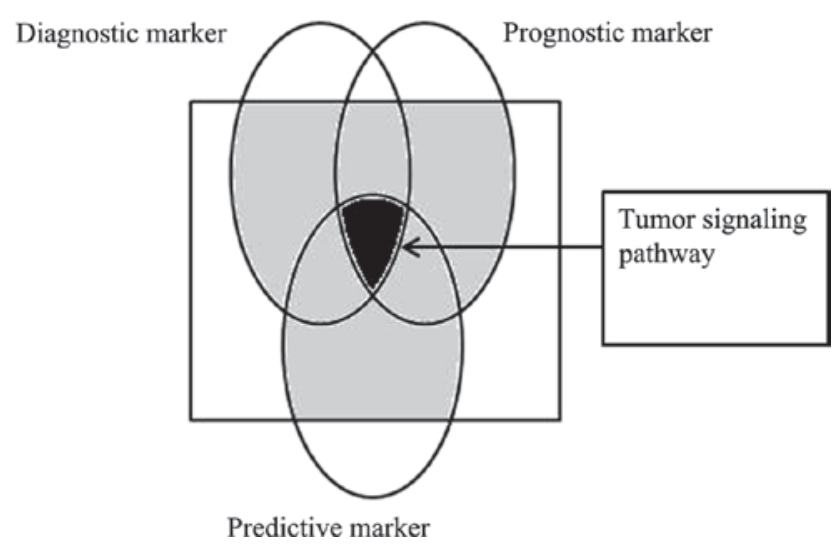

Figure 1. Representation of an ideal biomarker.

Lung cancer biomarkers on the basis of biomolecules. Lung carcinogenesis is a multi-step process resulting from the accumulation of altered molecules generated from genetic and epigenetic abnormalities of genes that are involved in cell cycle, senescence, apoptosis, repair, differentiation and cell migration controls $(9,29)$. There are several distinct types of cancer biomarkers based on different areas: genetics, epigenetics, proteomics and metabolomics (22). Genetics-based cancer biomarkers utilize functions such as DNA arrays, polymerase chain reaction (PCR), reverse transcriptase polymerase chain reaction (RT-PCR), DNA sequencing and fluorescent in situ hybridization (FISH), to detect the genetic alterations occurring in the cancerous state. Recent development of epigenetic modification analyses has also improved tools for cancer biomarkers. Epigenetic modification usually occurs in the $\mathrm{CpG}$ island of the gene regulatory regions, which results in the downregulation of the gene expression $(30,31)$. Proteomics includes techniques such as mass spectrometry (MS), enzyme-linked immunosorbent assay (ELISA) and immunohistochemistry, and it utilizes these tools to discover novel cancer biomarkers and validate them in clinical trials. Other than using macromolecules such as proteins and DNAs, metabolomics is concerned with the study of low molecular weight molecules or metabolites such as amino acids, peptides, lipids and carbohydrates $(22,32)$.

$D N A$. Single nucleotide polymorphisms (SNPs) in many genes are major DNA markers including XRCCl, ATM and $p 53$ (33). Other major DNA markers include loss of heterozygosity ( $\mathrm{LOH})$, variation in copy number of genes, chromosomal aberrations at a gross cytogenetic level, such as translocation/fusion (BCR-ABL, PML-RARA translocation in leukemias), micro-satellite instability (MSI) and epigenetic modifications (27,34-36).

In many cases the inactivation is induced by loss of DNA or accidental chromosomal rearrangement during cell division. The most well-known, frequently-occurring abnormality is deletion of the short arm of chromosome 3 (3p), where several tumor suppressor genes (TSG) are present $(37,38)$. Loss of chromosomal material has also been detected in metaplastic epithelium tissues of current- or ex-smokers. The loss of one allele or $\mathrm{LOH}$ indicates a predisposing potential to lung cancers $(39,40)$. 
Table I. Currently available protein-based biomarkers in the detection of lung cancer.

\begin{tabular}{|c|c|c|c|c|c|}
\hline Biomarkers & Diagnosis & $\begin{array}{l}\text { Therapy } \\
\text { monitoring }\end{array}$ & $\begin{array}{l}\text { Prognosis } \\
\text { monitoring }\end{array}$ & Ontology & Details \\
\hline CEA & $\begin{array}{l}\text { AdenoCA, LCLC } \\
\quad(>10 \mu \mathrm{g} / \mathrm{l})\end{array}$ & $\begin{array}{l}\text { AdenoCA, } \\
\text { Advanced } \\
\text { NSCLC }\end{array}$ & $\begin{array}{l}\text { AdenoCA, } \\
\text { NSCLC }\end{array}$ & $\begin{array}{l}\text { Cellular component } \\
\text { Cell membrane: lipid anchor } \\
\text { Immunoglobulin } \\
\text { superfamily }\end{array}$ & $\begin{array}{l}\text { In combination with } \\
\text { CYFRA } \\
\text { Often elevated } \\
\text { in smokers }\end{array}$ \\
\hline CYFRA21-1 & $\begin{array}{c}\text { NSCLC (23-70\%), SCC } \\
\text { (no., sensitivity) }\end{array}$ & $\begin{array}{l}\text { Advanced } \\
\text { NSCLC }\end{array}$ & $\begin{array}{l}\text { NSCLC, } \\
\text { SCC }\end{array}$ & $\begin{array}{l}\text { Structural constitutent of } \\
\text { cytoskeleton }\end{array}$ & $\begin{array}{l}\text { Often elevated in patients } \\
\text { with benign lung diseases }\end{array}$ \\
\hline TPA & NSCLC, SCC & - & NSCLC & & - \\
\hline ProGRP & $\begin{array}{l}\text { SCLC (47-86\%) } \\
\text { (>200 ng/l, highly } \\
\text { suspicious) } \\
\text { (no., sensitivity) }\end{array}$ & SCLC & - & $\begin{array}{l}\text { Neuropeptide hormone } \\
\text { activity }\end{array}$ & $\begin{array}{l}\text { Increased in renal failure } \\
\text { and certain benign lung diseases } \\
\text { In combination with NSE }\end{array}$ \\
\hline NSE & $\begin{array}{c}\text { SCLC } \\
(>100 \mu \mathrm{g} / \mathrm{l}, \text { high } \\
\text { probability) } \\
\text { (sensitivity for SCLC, } \\
\text { high } 74 \%)\end{array}$ & SCLC & SCLC & $\begin{array}{l}\text { Phosphoglycerate } \\
\text { dehydrogenase activity } \\
\text { Subcellular location } \\
\text { (cytoplasm) }\end{array}$ & $\begin{array}{l}\text { In combination with } \\
\text { ProGRP } \\
\text { May correlate with } \\
\text { short survival } \\
\text { Increased in } \\
\text { inflammatory diseases }\end{array}$ \\
\hline $\begin{array}{l}\text { Tumor M2- } \\
\text { pyruvate } \\
\text { kinase }\end{array}$ & $\begin{array}{c}\text { AdenoCA } \\
\text { (sensitivty for SCLC, } \\
50-71 \% \text { ) }\end{array}$ & - & AdenoCA & $\begin{array}{l}\text { Pyruvate kinase activity } \\
\text { Glycolysis } \\
\text { Cytoplasm }\end{array}$ & $\begin{array}{l}\text { Increased in multiple } \\
\text { malignant and certain } \\
\text { inflammatory diseases }\end{array}$ \\
\hline
\end{tabular}

CEA, carcinoembryonic antigen; AdenoCA, adenocarcinoma; NSCLC, non-small cell lung cancer; CYFRA 21-1, cytokeratin 19 fragment; SCC, squamous cell carcinoma; ProGRP, progastrin-releasing peptide; SCLC, small cell lung cancer; NSE, neuron-specitic enolase.

Notably, besides nuclear aberrations, alterations in mitochondrial DNA (mtDNA) molecules are suggested as clear biomarkers for lung cancers $(41,42)$. Epigenetic modification of nucleic acids and associated proteins (histones and non-histones) are important in carcinogenesis $(35,43,44)$. Histone de-acetylation, lysine-specific histone-H3 methylation and promoter region $\mathrm{CpG}$ methylation modulate transcription of tumor-suppressor genes (CDKN2A, TP53, APC, BRCA1) and DNA mismatch-repair genes (MLH1 or the O6-methyl-guanine-DNAmethyltransferase gene, MGMT). Gene silencing by $\mathrm{CpG}$ methylation is one of the best-characterized epigenetic modifications to date $(35,41,44)$. The degree of methylation in sputum/serum from patients with lung cancer is directly implicated in the severity of the lesions.

$R N A$. Messenger RNAs (mRNAs) are promising biomarkers, and microarrays represent a powerful approach for their discovery in blood. More recent microarray studies have identified additional early detection signatures. Some of the methods used to detect cancer biomarkers at the RNA expression level include quantitative reverse transcription polymerase chain reaction (RT-qPCR), serial analysis of gene expression (SAGE), differential display, bead-based methods and microfluid card and micro-array analysis (45). A study of peripheral blood mononuclear cells (PBMCs) from lung cancer patients identified a signature of 29 genes that distinguished patients from controls (46). Panels of mRNA biomarkers for early detection have also been identified in bladder, breast and renal carcinomas (47-49). These studies suggest that blood-based mRNA signatures may be potentially useful tools for the early detection of lung cancer.

The potential use of microRNAs (miRNAs) as biomarkers for lung cancer has also been demonstrated. Several studies have identified pathognomonic or tissue-specific miRNA expression profiles in lung and other types of cancer (50-52). There is sufficient evidence indicating that miRNA expression profiles could be used to classify lung cancer, which also suggests a correlation between disease prognosis and therapeutic outcome. miRNA could act as a tumor suppressor, as well as an oncogene (53). For example, in lung cancer, let-7 is a suppressor for RAS. mir17 and mir21 clusters are oncogenic and modulate PTEN and TGF $\beta$-RII (52). These observations emphasize the potential application of miRNAs as biomarkers for diagnosis, prognosis, stage, risk stratification and prediction and drug-responses in patients with cancer.

Protein markers. Several proteins are currently in use for the detection of lung cancer (Table I). An oncofetal protein, CEA and cytokeratin 19-fragment (CYFRA 21-1) proteins have been reported as potential indices for monitoring response to treatment among advanced NSCLC patients $(5,54)$. Neuron-specific enolase (NSE) and progastrinreleasing peptide (ProGRP) are also available to use as lung cancer biomarkers for SCLC $(55,56)$. However, these protein biomarkers also usually lack lung-cancer specificity. 
There are other potential lung cancer biomarker molecules that are still not available for clinical use. The potency of serum amyloid A $(57,58)$ and haptoglobin- $\alpha 2(59,60)$ as lung cancer biomarkers require more clinical validation before they are approved for clinical use. Plasma granulocyte colonystimulating factor (G-CSF) levels were significantly increased in patients with lung cancer, particularly in the advanced TNM stages $(61,62)$. These results suggest that plasma G-CSF could be used to support the diagnostic process of lung cancer staging and as an indicator of metastasis.

Lung cancer and proteomics. Comprehensive and in-depth discovery of the disease proteome is an important issue in recent proteomic developments. Improvement in sample preparation tools will reduce the intrinsic limitations in biological samples, such as variation among individuals, differences in genetic make-up and non-specific changes $(63,64)$.

Protein-based lung cancer biomarkers are derived from the techniques of classical 2-dimensional (2-D) fluorescence difference gel electrophoresis (DIGE), polyacrylamide gel electrophoresis (PAGE), mass spectroscopy, matrix-associated laser absorption desorption ionization time-of-flight (MALDI-TOF), surface-enhanced laser absorption desorption ionization time-of-flight (SELDITOF) and reverse phase microarray (65-67).

Quantum dots and nanoparticles are recent additions to the technologies available to assess the potential of protein molecules as cancer biomarkers (68). Quantitative proteomics have been utilized to discover biomarkers in lung cancer, such as stable isotope labeling with amino acids in cell culture (SILAC), iTRAQ and liquid chromatography-MS/MS (LC-MS/MS) (69-71).

Circulating tumor cells. Circulating tumor cells (CTCs) are indicators of cancer and have been extensively reviewed $(72,73)$. For the early detection of cancer, one challenge is to find highly specific markers that are able to address extremely low signal-to-noise ratio. Detection of CTCs currently relies on a single marker, the epithelial cell surface epitope EpCAM. Although EpCAM is an excellent epithelial cell marker, it is not expressed on all cancer cells (74). Emerging approaches include the use of gene mutations, antibody cocktails, negative selections and filtrations on the basis of cell size or density (73).

\section{Conclusion}

The application of biomarkers for the early detection of all types of cancer is of significant potential value and deserves a similarly significant share of funding. However, in lung cancer, there are no sensitive and specific biomarkers such as prostate specific antigen for prostate cancer. Several biomarkers will probably have to be used together, including DNA- and RNA-based biomarkers, protein biomarkers, proteomics and CTCs.

Assay sensitivity and specificity need to be improved, techniques must be standardized and validated, and legislation on biomarkers needs to be regulated more closely. We may be confident that general progress and marked new discoveries will continue, as techniques for earlier detection are being developed, which could have major impacts. The progress of clinical medicine quite significantly depends on the testing of novel theories.

\section{References}

1. Lee YS, Oh YM, Shim TS, Kim WS, An JS, Choi CM and Jang SH: The clinical outcomes of photodynamic therapy in early lung cancer patients. Tuberc Respir Dis 71: 266-270, 2011.

2. Alberg AJ, Ford JG and Samet JM; American College of Chest Physicians: Epidemiology of lung cancer: ACCP evidence-based clinical practice guidelines (2nd edition). Chest 132: 29S-55S, 2007.

3. Ferlay J, Shin HR, Bray F, Forman D, Mathers C and Parkin DM: Estimates of worldwide burden of cancer in 2008: GLOBOCAN 2008. Int J Cancer 127: 2893-2917, 2010.

4. Ministry for Health, Welfare and Family Affairs: 2008 Annual Report of Cancer Statistics in Korea. Ministry for Health, Welfare and Family Affairs, Seoul, 2010.

5. Molina R, Filella X, Auge JM, et al: Tumor markers (CEA, CA 125, CYFRA 21-1, SCC, and NSE) in patients with non-small cell lung cancer as an aid in histological diagnosis, and prognosis. Comparison with the main clinical and pathological prognostic factors. Tumour Biol 24: 209-218, 2003.

6. American Cancer Society: Cancer Prevention \& Early Detection Facts \& Figures, 2011. American Cancer Society, Atlanta, 2011.

7. Scott WJ, Howington J, Feigenberg S, Movsas B and Pisters K; American College of Chest Physicians: Treatment of non-small cell lung cancer stage I and stage II: ACCP evidence-based clinical practice guidelines (2nd edition). Chest 132: 234S-242S, 2007.

8. Hirsch FR, Merrick DT and Franklin WA: Role of biomarkers for early detection of lung cancer and chemoprevention. Eur Respir J 19: 1151-1158, 2002.

9. Brambilla C, Fievet F, Jeanmart M, de Fraipont F, Lantuejoul S, Frappat V, Ferretti G, Brichon PY and Moro-Sibilot D: Early detection of lung cancer: role of biomarkers. Eur Respir J Suppl 39: $36 \mathrm{~S}-44 \mathrm{~S}, 2003$

10. Brower V: Biomarker studies abound for early detection of lung cancer. J Natl Cancer Inst 101: 11-13, 2009.

11. Peng G, Tisch U, Adams O, Hakim M, Shehada N, Broza YY, Billan S, Abdah-Bortnyak R, Kuten A and Haick H: Diagnosing lung cancer in exhaled breath using gold nanoparticles. Nat Nanotechnol 4: 669-673, 2009.

12. van Klaveren RJ, Oudkerk M, Prokop M, et al: Management of lung nodules detected by volume CT scanning. N Engl J Med 361: 2221-2229, 2009.

13. Yau G, Lock M and Rodrigues G: Systematic review of baseline low-dose CT lung cancer screening. Lung Cancer 58: 161-170, 2007.

14. Ilie M, Mazure NM, Hofman V, Ammadi RE, Ortholan C, Bonnetaud C, Havet K, Venissac N, Mograbi B, Mouroux J, Pouysségur J and Hofman P: High levels of carbonic anhydrase IX in tumour tissue and plasma are biomarkers of poor prognostic in patients with non-small cell lung cancer. Br J Cancer 102: $1627-1635,2010$.

15. Yee J, Sadar MD, Sin DD, Kuzyk M, Xing L, Kondra J, McWilliams A, Man SF and Lam S: Connective tissue-activating peptide III: a novel blood biomarker for early lung cancer detection. J Clin Oncol 27: 2787-2792, 2009.

16. Patz EF, Campa MJ, Gottlin EB, Kusmartseva I, Guan XR and Herndon JE II: Panel of serum biomarkers for the diagnosis of lung cancer. J Clin Oncol 25: 5578-5583, 2007.

17. Palmisano WA, Divine KK, Saccomanno G, Gilliland FD, Baylin SB, Herman JG and Belinsky SA: Predicting lung cancer by detecting aberrant promoter methylation in sputum. Cancer Res 60: 5954-5958, 2000.

18. Belinsky SA, Klinge DM, Dekker JD, Smith MW, Bocklage TJ, Gilliland FD, Crowell RE, Karp DD, Stidley CA and Picchi MA: Gene promoter methylation in plasma and sputum increases with lung cancer risk. Clin Cancer Res 11: 6505-6511, 2005.

19. Gray RD, Duncan A, Noble D, Imrie M, O'Reilly DS, Innes JA, Porteous DJ, Greening AP and Boyd AC: Sputum trace metals are biomarkers of inflammatory and suppurative lung disease. Chest 137: 635-641, 2010.

20. Kennedy TC, Miller Y and Prindiville S: Screening for lung cancer revisited and the role of sputum cytology and fluorescence bronchoscopy in a high-risk group. Chest 117: 72S-79S, 2000.

21. Hirsch J, Hansen KC, Burlingame AL and Matthay MA: Proteomics: current techniques and potential applications to lung disease. Am J Physiol Lung Cell Mol Physiol 287: L1-L23, 2004.

22. Sung HJ and Cho JY: Biomarkers for the lung cancer diagnosis and their advances in proteomics. BMB Rep 41: 615-625, 2008. 
23. Potti A, Mukherjee S, Petersen R, et al: A genomic strategy to refine prognosis in early-stage non-small-cell lung cancer N Engl J Med 355: 570-580, 2006.

24. Pleasance ED, Stephens PJ, O'Meara S, et al: A small-cell lung cancer genome with complex signatures of tobacco exposure. Nature 463: 184-190, 2010.

25. Mitsudomi T and Yatabe Y: Mutations of the epidermal growth factor receptor gene and related genes as determinants of epidermal growth factor receptor tyrosine kinase inhibitors sensitivity in lung cancer. Cancer Sci 98: 1817-1824, 2007.

26. McDermott U, Downing JR and Stratton MR: Genomics and the continuum of cancer care. N Engl J Med 364: 340-350, 2011.

27. Verma M and Manne U: Genetic and epigenetic biomarkers in cancer diagnosis and identifying high risk populations. Crit Rev Oncol Hematol 60: 9-18, 2006.

28. Habis AH, Vernon SD, Lee DR, Verma M and Unger U: Molecular quality of exfoliated cervical cells: implications for molecular epidemiology and biomarker discovery. Cancer Epidemiol Biomarkers Prev 13: 492-496, 2004.

29. Martin KJ, Fournier MV, Reddy GP and Pardee AB: A need for basic research on fluid-based early detection biomarkers. Cancer Res 70: 5203-5206, 2010.

30. Baylin SB: DNA methylation and gene silencing in cancer. Nat Clin Pract Oncol 2 (Suppl 1): S4-S11, 2005.

31. Belinsky SA: Gene-promoter hypermethylation as a biomarker in lung cancer. Nat Rev Cancer 4: 707-717, 2004.

32. Parker CE, Pearson TW, Anderson NL and Borchers CH: Mass-spectrometry-based clinical proteomics-a review and prospective. Analyst 135: 1830-1838, 2010.

33. Qian B, Zhang H,Zhang L, Zhou X, Yu H and Chen K: Association of genetic polymorphisms in DNA repair pathway genes with non-small cell lung cancer risk. Lung Cancer 73: 138-146, 2011.

34. Chatterjee SK and Zetter BR: Cancer biomarkers: knowing the present and predicting the future. Future Oncol 1: 37-50, 2005.

35. Verma M: Human epigenome and cancer. In: Human Genome Epidemiology. Khoury M, Bedrosian SR, Gwinn M, Higgins JPT, Ioannidis JPA and Little J (eds). 2nd edition. Oxford University Press, London, pp551-558, 2009.

36. Sidransky D: Emerging molecular markers of cancer. Nat Rev Cancer 2: 210-219, 2002 .

37. Zabarovsky ER, Lerman MI and Minna JD: Tumor suppressor genes on chromosome $3 p$ involved in the pathogenesis of lung and other cancers. Oncogene 21: 6915-6935, 2002.

38. Xue X, Zhu YM and Woll PJ: Circulating DNA and lung cancer Ann NY Acad Sci 1075: 154-164, 2006.

39. Mao L, Lee JS, Kurie JM, et al: Clonal genetic alterations in the lungs of current and former smokers. J Natl Cancer Inst 89: $857-862,1997$.

40. Wistuba II, Behrens C, Milchgrub S, Bryant D, Hung J, Minna JD and Gazdar AF: Sequential molecular abnormalities are involved in the multistage development of squamous cell lung carcinoma. Oncogene 18: 643-650, 1999.

41. Verma M and Srivastava S: Epigenetics in cancer: implications for early detection and prevention. Lancet Oncol 3: 755-763, 2002

42. Verma M and Kumar D: Application of mitochondrial genome information in cancer epidemiology. Clin Chim Acta 383: 41-50, 2007.

43. Enokida H, Shiina H, Igawa M, et al: $\mathrm{CpG}$ hypermethylation of MDR1 gene contributes to the pathogenesis and progression of human prostate cancer. Cancer Res 64: 5956-5962, 2004.

44. Kaneuchi M, Sasaki M, Tanaka Y, Shiina H, Verma M, Ebina Y, Nomura E, Yamamoto R, Sakuragi N and Dahiya R: Expression and methylation status of 14-3-3 sigma gene can characterize the different histological features of ovarian cancer. Biochem Biophys Res Commun 316: 1156-1162, 2004

45. Velculescu VE, Zhang L, Vogelstein B and Kinzler KW: Serial analysis of gene expression. Science 270: 484-487, 1995.

46. Showe MK, Vachani A, Kossenkov AV, et al: Gene expression profiles in peripheral blood mononuclear cells can distinguish patients with non-small cell lung cancer from patients with nonmalignant lung disease. Cancer Res 69: 9202-9210, 2009.

47. McConkey DJ, Lee S, Choi W, Tran M, Majewski T, Lee S, Siefker-Radtke A, Dinney C and Czerniak B: Molecular genetics of bladder cancer: emerging mechanisms of tumor initiation and progression. Urol Oncol 28: 429-440, 2010.

48. Hennig G, Gehrmann M, Stropp U, Brauch H, Fritz P, Eichelbaum M, Schwab M and Schroth W: Automated extraction of DNA and RNA from a single formalin-fixed paraffin-embedded tissue section for analysis of both single-nucleotide polymorphisms and mRNA expression. Clin Chem 56: 1845-1853, 2010.
49. Hoffmann NE, Sheinin Y, Lohse CM, Parker AS, Leibovich BC, Jiang Z and Kwon ED: External validation of IMP3 expression as an independent prognostic marker for metastatic progression and death for patients with clear cell renal cell carcinoma. Cancer 112: 1471-1479, 2008.

50. Yanagihara N, Caplen N, Bowman E, et al: Unique microRNA molecular profiles in lung cancer diagnosis and prognosis. Cancer Cell 9: 189-198, 2006

51. Rosenfeld N, Aharonov R, Meiri E, et al: MicroRNAs accurately identify cancer tissue origin. Nat Biotechnol 26: 462-469, 2008.

52. Zhang W, Winder T, Ning Y, et al: A let-7 microRNA-binding site polymorphism in 3'-untranslated region of KRAS gene predicts response in wild-type KRAS patients with metastatic colorectal cancer treated with cetuximab monotherapy. Ann Oncol 22: 104-109, 2011.

53. Shenouda SK and Alahari SK: MicroRNA function in cancer: oncogene or a tumor suppressor? Cancer Metastasis Rev 28 369-378, 2009.

54. Kulpa J, Wojcik E, Radkowski A, Kolodziejski L and Stasik Z: CYFRA 21-1, TPA-M, TPS, SCC-Ag, and CEA in patients with squamous cell lung cancer, and in chemical industry workers as a reference group. Anticancer Res 20: 5035-5040, 2000.

55. Lamy P, Grenier J, Kramar A and Pujol JL: Pro-gastrin-releasing peptide, neuron specific enolase, and chromogranin A as serum markers of small cell lung cancer. Lung Cancer 29: 197-203, 2000

56. Schneider J, Philipp M, Velcovsky HG, Morr H and Katz N: Pro-gastrin-releasing peptide (ProGRP), neuron specific enolase (NSE), carcinoembryonic antigen (CEA), and cytokeratin 19-fragments (CYFRA 21-1) in patients with lung cancer in comparison to other lung diseases. Anticancer Res 23: 885-893, 2003.

57. Cho WC, Yip TT, Cheng WW and Au JS: Serum amyloid A is elevated in the serum of lung cancer patients with poor prognosis. Br J Cancer 102: 1731-1735, 2010.

58. Cremona M, Calabrò E, Randi G, De Bortoli M, Mondellini P, Verri C, Sozzi G, Pierotti MA, La Vecchia C, Pastorino U and Bongarzone I: Elevated levels of the acute-phase serum amyloid are associated with heightened lung cancer risk. Cancer 116: $1326-1335,2010$

59. Abdullah M, Marwitz S, Kähler D, Schultz H, Kugler C, Zabel P, Vollmer E and Goldmann T: Pulmonary haptoglobin: a new marker for adenocarcinomas of the lung? Pathology 43: 70-72, 2011.

60. Shah A, Singh H, Sachdev V, Lee J, Yotsukura S, Salgia R and Bharti A: Differential serum level of specific haptoglobin isoforms in small cell lung cancer. Curr Proteomics 7: 49-65, 2010.

61. Coward JI, Nathavitharana R and Popat S: True hypoglycaemia secondary to treatment with granulocyte colony stimulating factor (G-CSF) in a diabetic patient with non-small cell lung cancer. Lung Cancer 75: 133-135, 2012.

62. Song JS, Kim SY, Jo HJ, et al: The role and significance of biomarker for plasma G-CSF in patients with primary lung cancer. Tuber Respir Dis 66: 444-450, 2009.

63. Hanash SM, Pitteri SJ and Faca VM: Mining the plasma proteome for cancer biomarkers. Nature 452: 571-579, 2008.

64. Taguchi A, Politi K, Pitteri SJ, et al: Lung cancer signatures in plasma based on proteome profiling of mouse tumor models. Cancer Cell 20: 289-299, 2011.

65. Jeong HC, Kim GI, Cho SH, Lee KH, Ko JJ, Yang JH and Chung KH: Proteomic analysis of human small cell lung cancer tissues: up-regulation of coactosin-like protein-1. J Proteome Res 10: 269-276, 2011

66. Du J, Yang S, Lin X, Bu L, Nan Y, Huo S and Shang W: Use of anchorchip-time-of-flight spectrometry technology to screen tumor biomarker proteins in serum for small cell lung cancer. Diagn Pathol 5: 60, 2010.

67. Rahman SM, Gonzalez AL, Li M, et al: Lung cancer diagnosis from proteomic analysis of preinvasive lesions. Cancer Res 71: 3009-3017, 2011.

68. Seydel C: Quantum dots get wet. Science 300: 80-81, 2003

69. Guha U, Chaerkady R, Marimuthu A, et al: Comparisons of tyrosine phosphorylated proteins in cells expressing lung cancerspecific alleles of EGFR and KRAS. Proc Natl Acad Sci USA 105: 14112-14117, 2008

70. Haura EB, Müller A, Breitwieser FP, Li J, Grebien F, Colinge J and Bennett KL: Using iTRAQ combined with tandem affinity purification to enhance low-abundance proteins associated with somatically mutated EGFR core complexes in lung cancer. J Proteome Res 10: 182-190, 2011 
71. Zeng X, Hood BL, Sun M, Conrads TP, Day RS, Weissfeld JL, Siegfried JM and Bigbee WL: Lung cancer serum biomarker discovery using glycoprotein capture and liquid chromatography mass spectrometry. J Proteome Res 9: 6440-6449, 2010.

72. Taniguchi K, Uchida J, Nishino K, Kumagai T, Okuyama T, Okami J, Higashiyama M, Kodama K, Imamura F and Kato K: Quantitative detection of EGFR mutations in circulating tumor DNA derived from lung adenocarcinomas. Clin Cancer Res 17: 7808-7815, 2011.
73. Kaiser J: Medicine. Cancer's circulation problem. Science 327 1072-1074, 2010.

74. Pantel K, Alix-Panabieres C and Riethdorf S: Cancer micrometastases. Nat Rev Clin Oncol 6: 339-351, 2009. 